\title{
Arginine Requirements and Optimum Balance between Dietary Arginine and Lysine in Broiler Chicks
}

\author{
Keisuke UENO and Teru ISHIBASHI* \\ Graduate School of Science and Technology, Niigata University, \\ Niigata-shi $950-2102$
}

(Received December 5, 1997)

\begin{abstract}
The reported arginine (Arg) requirements range widely by investigators, and Arg requirements are affected by dietary lysine (Lys) levels. Therefore, this experiment was conducted to ascertain the interrelationship between Arg requirements and dietary Lys levels using body weight gain and plasma concentration (PC) of Arg as parameters. Female broiler chicks at 8 days of age were divided into 20 dietary groups of 10 chicks, housed individually, and given free access to the experimental diets for 10 days. The Arg- and Lys-deficient basal diets were consisted of corn, corn gluten meal, soybean meal and wheat bran, and contained $0.65 \%$ Arg, $0.80 \%$ Lys, $18.7 \%$ crude protein and $3.20 \mathrm{kcal}$ metabolizable energy (ME) $/ \mathrm{g}$ of diet. To the basal diet, four graded levels of Lys were added, and to each Lys diet, graded five levels of Arg were added. The body weight (BW) gain of chicks increased with increasing dietary Arg levels and then decreased in all dietary Lys levels. The PC of Arg increased slowly and then linearly with increasing dietary Arg levels. The Arg requirements (Y, \% of diet) determined from BW gain and $\mathrm{PC}$ of Arg increased linearly with increasing dietary Lys levels (X, \% of diet, $0.80 \leqq \mathrm{X} \leqq 1.40$ for BW gain and $0.80 \leqq X \leqq 1.70$ for $\mathrm{PC}$ of $\mathrm{Arg})$ as follows. $\mathrm{Y}=1.15 \mathrm{X}-0.21\left(\mathrm{r}^{2}=0.944\right)$ for $\mathrm{BW}$ gain, and $\mathrm{Y}=$ $1.10 \mathrm{X}-0.21\left(\mathrm{r}^{2}=0.991\right)$ for PC of Arg. When BW gain was plotted against dietary levels of Lys and $\mathrm{Arg}$, the maximum BW gain was achieved at $1.10 \% \mathrm{Lys}$ and $1.36 \% \mathrm{Arg}$ and the ratio of Arg/Lys was estimated to be 1.24 .
\end{abstract}

Anim. Sci. Technol. (Jpn.) 69 (8) : 760-767, 1998

Key words : Arginine requirement, Broiler chick, Crude protein, Lysine, Plasma arginine

In the practical low crude protein (CP) broiler diet supplemented with crystalline lysine (Lys) and methionine, arginine (Arg) is liable to be one of the limiting amino acids (AA) at young age. Therefore, Table 1 shows the many reports on Arg requirements of broilers at a young age. The values in the cited reports and NRC are shown in Table 1 , which range widely from $0.80^{7)}$ to $1.40 \%{ }^{3)}$ of diet. This wide range of Arg requirements is not unreasonable, because AA requirements are affected by many factors, such as dietary levels of $\mathrm{CP}^{10,20)}$ or metabolically related $\mathrm{AA}^{32)}$, age ${ }^{2,15)}$, strain of chicks $^{23)}$ and so on.

From the data except NRC $(1994)^{22)}$ in Table 1, Arg requirements ( $Y, \%$ of diet) increase with increasing dietary $\mathrm{CP}$ levels (X, \% of diet), and are expressed as a function of dietary $\mathrm{CP}$ levels as follows. However, the obtained coeffciency was low.

$$
\mathrm{Y}=0.046 \mathrm{X}+0.31 \quad \mathrm{r}^{2}=0.410 \quad 14.5 \leqq \mathrm{X} \leqq 23.0
$$

\footnotetext{
* Present address : Faculty of Veterinary and Animal Science, Nippon Veterinary and Animal Science University, Musashino-shi 180-8602
} 
It is well known that there is an antagonism between Arg and Lys ${ }^{1,7,8,17}$. D'Mello and Lewis $^{7.8)}$ clearly showed that the Arg requirements increased with increasing dietary Lys levels. From their data in Table 1, the Arg requirements ( $\mathrm{Y}, \%$ of diet) are expressed as a function of dietary Lys levels (X, \% of diet) as follows.

$$
\mathrm{Y}=0.47 \mathrm{X}+0.29 \quad \mathrm{r}^{2}=1.00 \quad 1.10 \leqq \mathrm{X} \leqq 1.85
$$

However, the calculated ratios of Arg/Lys are lower than the others in Table 1. The Arg requirements are expressed as follows

$$
\mathrm{Y}=1.13 \mathrm{X}-0.03 \quad \mathrm{r}^{2}=0.710 \quad 0.83 \leqq \mathrm{X} \leqq 1.18
$$

Ueno et al ${ }^{32)}$ confirmed that the depression of performance caused by Arg deficiency was intensified by addition of Lys, but not of other AA individually to the Arg deficient diet. When a large amount of glutamic acid was added to the diet as a source of nitrogen, the requirement of Arg was not affected (not yet published). These observations indicate that the Arg requirements is affected by dietary Lys, but not by other AA and CP.

It is well documented that $\mathrm{AA}$ requirements determined from plasma concentration (PC) of AA agree well with those by performance in many species, including rats ${ }^{29}$, chicks ${ }^{7,36)}$, laying hens ${ }^{16,34)}$, pigs ${ }^{19)}$, and young $\operatorname{men}^{35)}$.

The present study was conducted to ascertain the Arg requirements and to estimate optimum balance between dietary Arg requirements and Lys in young female broilers using growing performance and $\mathrm{PC}$ of $\mathrm{AA}$ as parameters.

\section{Materials and Methods}

\section{Animal and design of experiment}

One-day-old Cobb strain female broiler chicks were obtained from a commercial hatchery and group-fed a stock diet containing $23 \%$ $\mathrm{CP}$ and $3.20 \mathrm{kcal}$ metabolizable energy $(\mathrm{ME}) / \mathrm{g}$ of diet. On day 8 posthatching, the chicks were divided into 20 dietary groups of 10 chicks with the same average body weight (BW) of $150 \pm 1 \mathrm{~g}$, housed individually in wire cages and given free access to the experimental diets and water for a 10 day experimental period in an environmentally controlled room $\left(23 \pm 3^{\circ} \mathrm{C}\right.$, and lights on $4: 00$ to $20: 00$ ).

At the termination of the experiment, body weight and feed intake were recorded, and blood samples were taken from the wing vein with heparinized syringes. The PC of AA was determined with an HPLC (Simadzu LC 6 A) as described by Fujimura et al..$^{9}$.

\section{Experimental diet}

The basal diet consisted mainly of corn, corn gluten meal, soybean meal and wheat bran. To meet the AA requirements by NRC (1994) ${ }^{22)}$, five essential AA and glutamic acid (Glu) were added (Table 2). The basal diet contained $18.7 \% \mathrm{CP}, 0.65 \% \mathrm{Arg}, 0.80 \%$ Lys, $6.85 \%$ Glu and $3.20 \mathrm{kcal} \mathrm{ME} / \mathrm{g}$ of diet, and the AA composition of basal diet is shown in Table 2. To the basal diet, $0,0.3,0.6$ or $0.9 \%$ crystalline Lys was added by balancing the same amount of Glu to make $0.80,1.10,1.40$ and $1.70 \%$ Lys diets. To each Lys diet, crystalline Arg was added to make five diets with graded Arg levels, 0 to $0.40,0$ to $0.80,0$ to 1.20 , or 0 to $1.60 \%$, respectively, by balancing the same amount of Glu.

\section{Statistical analysis}

For statistical analysis, one-way analysis of variance was employed using the General Linear Model procedure in SAS ${ }^{\circledR}$ software ${ }^{27}$. Statistical significance of differences between treatment means was determined with the least significance difference test ${ }^{28)}$. Statements of significance are based upon $\mathrm{P}<0.05$ unless otherwise stated.

Response curves for performance (Y, BW gain, \% of diet or $\mathrm{mg} / \mathrm{chick} /$ day) to Arg intake (X,\% of diet or $\mathrm{mg} / \mathrm{chick} /$ day) were fitted with an exponential equation presented by Toyomizu et $a l^{\text {s1) }}$ :

$$
\mathrm{Y}=(\mathrm{A}-\mathrm{BX})\left(1-\mathrm{e}^{-\mathrm{C}(\mathrm{X}-\mathrm{D})}\right)
$$

The Arg requirements for the maximum performance were estimated as lower $\mathrm{X}$ level at 
$95 \%$ of the maximum response.

The calculated response surface was also conducted by a following equation ${ }^{30)}$.

$$
\mathrm{Y}=\mathrm{b}_{0}+\mathrm{b}_{1} \mathrm{X}_{1}+\mathrm{b}_{2} \mathrm{X}_{2}+\mathrm{b}_{3} \mathrm{X}_{1}^{2}+\mathrm{b}_{4} \mathrm{X}_{2}^{2}+\mathrm{b}_{5} \mathrm{X}_{1} \mathrm{X}_{2}
$$

Where $\mathrm{Y}$ represents the $\mathrm{BW}$ gain, $\mathrm{X}_{1}$ is dietary Arg levels (\%) and $X_{2}$ is dietary Lys levels (\%).

The Arg requirements were also estimated from the PC of Arg using a broken line model by Ohtsuka and Yoshihara ${ }^{24)}$.

\section{Results}

The body weight gain and feed intake increased with increasing dietary Arg levels and then decreased at all dietary Lys levels. The maximum BW gain achieved on the respective Lys diets increased and then decreased with increasing dietary Lys levels (Table 4 and Fig. 1).

The Arg requirements were estimated to be $0.69,1.08,1.38$ and $1.14 \%$ for the maximum BW gain, and $0.66,1.00,1.35$ and 1.23 for feed efficiency $(\mathrm{FE})$ on the $0.80,1.10,1.40$, and $1.70 \%$ Lys diets, respectively.

When the maximum BW gain was achieved, the feed intake was estimated to be $52.8,52.5$, 525 and $52.4 \mathrm{~g} / \mathrm{chick} / \mathrm{day}$, respectively. Therefore, the Arg requirements were estimated to be $364,567,725$ and $597 \mathrm{mg} / \mathrm{chick} /$ day, respectively, for the $0.80,1.10,1.40$ and $1.70 \%$ Lys diets.

Except the values on the $1.70 \%$ Lys diets, the Arg requirements ( $\mathrm{Y}, \%$ of diet or $\mathrm{mg} / \mathrm{chick}$ / day) were expressed as a function of dietary Lys levels (X, \% of diet or $\mathrm{mg} / \mathrm{chick} / \mathrm{day}, 0.80 \leqq$ $\mathrm{X} \leqq 1.40$ ) as follows.

$$
\begin{array}{lcr}
Y(\%)=1.15 X-0.21 & r^{2}=0.944 \\
Y(m g / \text { chick } / \text { day })=602 X-110 & r^{2}=0.995
\end{array}
$$

The maximum BW gain estimated by formula (5) was achieved at $1.36 \% \mathrm{Arg}$ and $1.10 \%$ (Fig. 1).

The PC of Arg increased slowly and linearly with increasing dietary Arg levels on all dietary Lys diets (Table 4). From the PC of Arg, the Arg requirements were estimated to be 0.65 ,

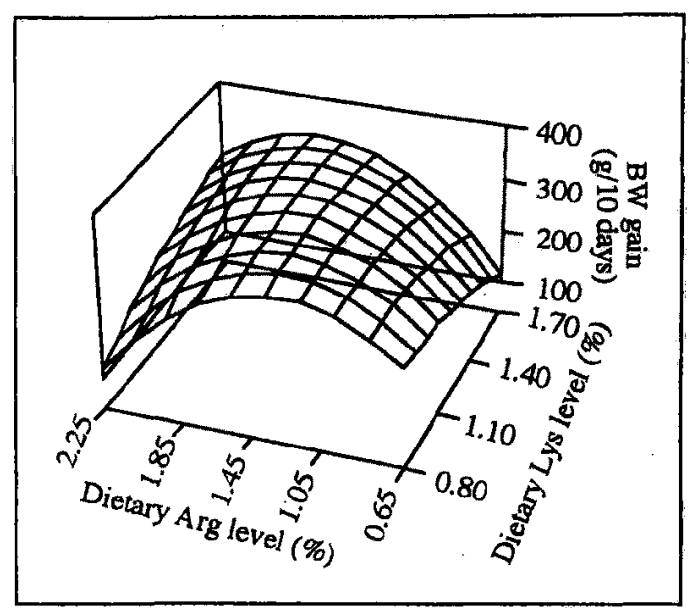

Fig. 1. Response surfaces depicting relationships between BW (body weight) gain and dietary levels of Lys and Arg.

$0.89,1.31$ and $1.65 \%$, respectively, for the 0.80 , $1.10,1.40$ and $1.70 \%$ Lys diets. The Arg requirements (Y, \% of diet) were expressed as a function of dietary Lys levels (X, \% of diet, 0.80 $\leqq X \leqq 1.70$ ) as follows.

$$
\mathrm{Y}(\%)=1.10 \mathrm{X}-0.21 \quad \mathrm{r}^{2}=0.991
$$

Since the feed intake was not recorded everyday, the Arg requirements were not expressed as $\mathrm{mg} / \mathrm{chick} /$ day in the case of $\mathrm{PC}$ of Arg.

The PC of Lys decreased linearly, and remained constant with increasing dietary Arg levels on all Lys diets. The break points were obtained at $<0.65,0.93,1.34$ and $1.70 \%$ dietary Arg levels, respectively, on the $0.80,1.10,1.40$, and $1.70 \%$ Lys diets.

To avoid complexity, only the PC of threonine are presented in Table 4. The PC of threonine decreased and remained constant with increasing dietary Arg levels at all dietary Lys levels as similar to other AA.

\section{Discussion}

To make diets with graded levels of Lys and Arg, both AA were added by balancing the same amount of Glu. Nitrogen and ME contents of Glu $(9.5 \%$ and $2.88 \mathrm{kcal} / \mathrm{g})$ were lower 
Arginine Requirement of Broilers

Table 1. Reported arginine (Arg) requirements of growing chicks (\%)

\begin{tabular}{|c|c|c|c|c|c|c|c|}
\hline \multirow{2}{*}{ References } & \multirow{2}{*}{$\underset{\text { requirement }}{\text { Arg }}$} & \multicolumn{2}{|c|}{ Dietary } & \multirow{2}{*}{ Diet } & \multirow{2}{*}{ Strain } & \multirow{2}{*}{ Sex } & \multirow{2}{*}{$\begin{array}{l}\text { Age } \\
\text { (day) }\end{array}$} \\
\hline & & Lys & $\mathrm{CP}$ & & & & \\
\hline $\mathrm{NRC}^{22)}$ & 1.25 & 1.01 & 23.0 & Compilations & - & - & $0-21$ \\
\hline Klain et $a l^{18)}$ & 1.08 & 1.01 & 23.0 & Purified & $\mathrm{NC}$ & M & $7-14$ \\
\hline Dean and $S \cot t^{6)}$ & 1.10 & 1. 12 & 17.7 & Purified & $\mathrm{NC}$ & M & $8-14$ \\
\hline Zimmerman and $S \operatorname{sot} t^{363}$ & 1.00 & 0.83 & 14.5 & Purified & $\mathrm{NC}$ & M & $15-22$ \\
\hline Sasse and Baker ${ }^{26)}$ & 0.95 & 0.91 & 14.8 & Purified & $\mathrm{NC}$ & M & $8-21$ \\
\hline Myung et $a L_{.}^{213}$ & 1. 24 & 1.10 & 23.0 & Purified & Cobb & M & $8-21$ \\
\hline Hurwitz et $a l_{x}{ }^{14)}$ & 1.33 & 1.18 & 19.2 & Computer & - & - & - \\
\hline Calet $^{4)}$ & 1.05 & 0.95 & 20.0 & Conventional & - & - & - \\
\hline Grigor'ev ${ }^{(1)}$ & 1.20 & 1.00 & 20.0 & Conventional & - & - & - \\
\hline Hewitt and Lewis ${ }^{193}$ & 0.86 & 0.85 & 18.0 & Conventional & Cobb & M & $7-21$ \\
\hline Packham and Payne ${ }^{25)}$ & 0.92 & 0.90 & 15.0 & Conventional & - & - & - \\
\hline Burton and Waldroup ${ }^{3)}$ & 1.40 & 1. 10 & 20.9 & Conventional & - & $\mathrm{M}, \mathrm{F}$ & $1-28$ \\
\hline Cuca and Jensen ${ }^{5)}$ & 1.25 & 1.20 & 23.0 & Conventional & $P A$ & M & $1-21$ \\
\hline \multirow[t]{4}{*}{ D'Mello and Lewis ${ }^{7}$} & 0.80 & 1.10 & 20.1 & Conventional & - & - & $7-21$ \\
\hline & 0.92 & 1.35 & 20.1 & & & & \\
\hline & 1.04 & 1.60 & 20.1 & & & & \\
\hline & 1.15 & 1.85 & 20.1 & & & & \\
\hline
\end{tabular}

Lys ; Lysine, CP ; crude protein, $\mathrm{N}$; New Hampshire, $\mathrm{C}$; Columbian, P ; Petersen, A ; Arbor Acre

than those of Lys $(19.2 \%$ and $4.60 \mathrm{kcal} / \mathrm{g})$ and Arg $(32.2 \%$ and $3.06 \mathrm{kcal} / \mathrm{g})$. Therefore, the diets were not isonitrogenous and isocaloric. The maximum differences of $\mathrm{CP}$ and $\mathrm{ME}$ between the lowest and highest Lys-Arg diets were calculated to be $2.8 \%$ and $0.02 \mathrm{kcal} / \mathrm{g}$ of diet. From formula 1, the Arg requirement increased only $0.11 \%$ by $2.8 \% \mathrm{CP}$. The obtained Arg requirements were $0.65 \%$ on the lowest Lys diet and $1.65 \%$ on the highest Lys diet, respectively. Therefore, the effect of difference of dietary CP might not be a factor to increase Arg requirements.

As shown in Table 1, the reported Arg requirements ranged widely from 0.80 to $1.40 \%$ of diet, which might be attributed to the wide range of dietary Lys and not to dietary $\mathrm{CP}$ levels. When $6.0 \%$ Glu was replaced by the same amount of corn starch, the same Arg requirements were obtained from the diets
Table 2. Composition of basal diet $(\%)$

\begin{tabular}{lr}
\hline \multicolumn{2}{c}{ Ingredients } \\
\hline Corn & 69.91 \\
Soybean meal $(44.0 \% \mathrm{CP})$ & 3.55 \\
Corn gluten meal $(60.2 \% \mathrm{CP})$ & 13.40 \\
Wheat bran & 3.00 \\
Soybean oil & 1.15 \\
Calcium carbonate & 1.20 \\
Tricalcium phosphate & 2.40 \\
Sodium chloride & 0.30 \\
Choline chloride & 0.10 \\
Vitamin-mineral premixture & 0.35 \\
Agar & 0.81 \\
Amino acid mixture & \\
& 3.83 \\
Analy tical composition & \\
CP, (\%) & 18.70 \\
ME, (kcal/g) & 3.20 \\
\hline
\end{tabular}

$\mathrm{CP}$; crude protein, ME; metabolizable energy

${ }^{1}$ Ueno et $a l^{32}$ ?

'See Table 3. 


\section{UENO and ISHIBASHI}

with or without addition of $6 \%$ Glu (unpublished data), which indicated that the dietary $\mathrm{CP}$ per se was not the direct cause of increment of Arg requirement with increasing dietary $\mathrm{CP}$ levels.

The Arg requirement determined from $\mathrm{PC}$ of Arg on the $1.70 \%$ Lys diets was fitted on the linear line as shown in formula 6 , but those from performance of broilers were less than that from the PC of Arg. Because the Arg: Lys ratios ranged almost the same width in all Lys diet, the depression of performance on the $1.70 \%$ Lys diet might not be caused by Arg deficiency and might be caused by Lys toxicity which was not alleviated by Arg.

The Arg requirements determined from $\mathrm{PC}$ of Arg were less than those from performance. As shown in the feeding standard ${ }^{22)}$, the Arg requirements decrease 0.15 points of percentage from 0 to 3 , to 3 to 6 weeks of age $(0.05 \%$ / weeks). Because the PC of AA responds within a short period after changing dietary AA levels ${ }^{32}$, the Arg requirements determined from the PC of Arg represents the requirement on the blood sampling day. However, those determined from performance are means for experimental period, especially for earlier period. Therefore, the former is less on than the latter.

As shown in formulas 6 and 8 , the Arg requirements increased at the rate 1.10 to 1.15 per percentage of dietary Lys levels. Following two reasons for the Arg requirements increased with increasing dietary Lys levels are suggested. As shown in Table 3, first, the maximum BW gain increased with increasing dietary Lys levels until $1.40 \%$. The BW gain accompanied the protein syntheses. Therefore, the Arg requirements increased with increasing of protein syntheses rate. The second reason is when the dietary Lys increased, the kidney arginase, which degraded Arg, was induced, and supply of more Arg was needed ${ }^{1}$.

From the data obtained in this study, it was
Table 3. Composition of amino acids (AA) in mixture, diet and NRC requirement (\%)

\begin{tabular}{|c|c|c|c|}
\hline & \multicolumn{2}{|c|}{$\mathrm{AA}$} & \multirow{2}{*}{$\underset{\text { requirement }}{\mathrm{NRC}}$} \\
\hline & AA mixture & Diet $^{\prime}$ & \\
\hline $\mathrm{Arg}^{2}$ & 0 to 1.60 & 0.65 to 2.25 & 1.25 \\
\hline $\mathrm{His}$ & - & 0.37 & 0.35 \\
\hline Ile & 0.18 & 0.80 & 0.80 \\
\hline Leu & - & 2.19 & 1. 20 \\
\hline Lys $^{2}$ & 0.57 to 0.90 & 0.80 to 1.70 & 1.10 \\
\hline Met & 0.15 & 0.60 & 0.50 \\
\hline Cys & - & 0.30 & 0.40 \\
\hline Phe & - & 0.83 & 0.72 \\
\hline Tyr & $\ldots$ & 0.70 & 0. 72 \\
\hline Thr & 0.26 & 0.80 & 0.80 \\
\hline $\operatorname{Trp}$ & 0.08 & 0.20 & 0.20 \\
\hline Val & 0.15 & 0.90 & 0.90 \\
\hline $\mathrm{Glu}^{2}$ & 0 to 2.50 & 4. 35 to 6.85 & - \\
\hline
\end{tabular}

${ }^{1}$ AA except Met, Cys and Trp were calculated from analytical data of feedstuffs.

${ }^{2}$ Met, Cys and Trp were calculated from Table by NRC (1994) $)^{22)}$.

L-Arg and L-Lys were substituted by the same amount of Glu.

clear that the Arg requirements increased with increasing dietary Lys levels (Formulas 6, 7 and 8 ) as observed by D'Mello and Lewis ${ }^{\text {?) }}$ (Formula 2) and other investigators (Formula 3). The Arg requirements increased $1.15 \%$ from BW gain and $1.10 \%$ from PC of Arg per percentage of dietary Lys, respectively in this study. However, the Arg requirements increased only $0.48 \%$ per percentage of dietary Lys in Formula 2 by D'Mello and Lewis ${ }^{7)}$. As indicated by them, the Arg requirements were lower compared to those determined at same dietary Lys levels by others. The lower Arg requirement was partly due to the method of calculation. Although the Arg requirements for the maximum performance were estimated as lower $\mathrm{X}$ level at $95 \%$ of the maximum response in this study, D'Mello and Lewis ${ }^{7)}$ estimated at $90 \%$ of maximum response. However, the reasons of lower ratio of $\mathrm{Arg} / \mathrm{Lys}$ was unclear.

Han and Baker ${ }^{12)}$ studied the effects of sex, 
Arginine Requirement of Broilers

Table 4. Effects of dietary lysine (Lys) and arginine (Arg) on the performance and plasma amino acid (AA) concentration of female broiler at 8 to $18 \mathrm{~d}$ of age

\begin{tabular}{|c|c|c|c|c|c|c|}
\hline \multicolumn{2}{|c|}{ Dietary } & \multirow{3}{*}{$\begin{array}{l}\text { Feed } \\
\text { intake } \\
(\mathrm{g} / 10 \mathrm{~d})\end{array}$} & \multirow{3}{*}{$\begin{array}{c}\text { Feed } \\
\text { efficiency } \\
(\mathrm{g} / \mathrm{g})\end{array}$} & \multicolumn{3}{|c|}{ Plasma concentration } \\
\hline Lys & Arg & & & Arg & Lys & Thr \\
\hline$-1 \%$ & & & & & $\mathrm{nmol} / \mathrm{m}$ & 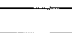 \\
\hline \multirow[t]{5}{*}{0.80} & 0.65 & 523 & 0.530 & $49^{d}$ & 173 & $2809^{\mathrm{a}}$ \\
\hline & 0.75 & 538 & 0.548 & $97^{c}$ & 144 & $1619^{\circ}$ \\
\hline & 0.85 & 539 & 0.555 & $191^{b}$ & 108 & $1553^{b}$ \\
\hline & 0.95 & 534 & 0.560 & $245^{a}$ & 106 & $1180^{\circ}$ \\
\hline & 1.05 & 545 & 0.561 & $282^{a}$ & 90 & $1612^{b}$ \\
\hline Pooled SE & & 16 & 0.011 & 5 & 25 & 34 \\
\hline \multirow[t]{5}{*}{1.10} & 0.65 & $459^{c}$ & $0.488^{\circ}$ & $62^{d}$ & $814^{\mathrm{n}}$ & $2288^{a}$ \\
\hline & 0.85 & $495^{b}$ & $0.561^{\text {ta }}$ & $87^{d}$ & $408^{b}$ & $1626^{\mathrm{a}}$ \\
\hline & 1.05 & $521^{2}$ & $0.611^{3}$ & $159^{\circ}$ & $282^{b c}$ & $771^{b}$ \\
\hline & 1.25 & $529^{a b}$ & $0.624^{3}$ & $250^{\circ}$ & $248^{a}$ & $859^{b}$ \\
\hline & I. 45 & $535^{\circ}$ & $0.615^{3}$ & $331^{a}$ & $225^{\mathrm{c}}$ & $772^{\mathrm{b}}$ \\
\hline Pooled SE & & 14 & 0.010 & 9 & 25 & 56 \\
\hline \multirow[t]{5}{*}{1.40} & 0.65 & $456^{a}$ & $0.371^{4}$ & $58^{d}$ & $1386^{\mathrm{a}}$ & $1981^{a}$ \\
\hline & 0.95 & $522^{b}$ & $0.496^{\circ}$ & $86^{d}$ & $846^{b}$ & $1705^{2}$ \\
\hline & 1.25 & $533^{b}$ & $0.585^{\circ}$ & $.127^{\mathrm{c}}$ & $637^{b}$ & $789^{\circ}$ \\
\hline & 1.55 & $532^{b}$ & $0.636^{a}$ & $207^{b}$ & $621^{\circ}$ & $695^{\circ}$ \\
\hline & 1.85 & $528^{b}$ & $0.626^{a}$ & $324^{a}$ & $567^{b}$ & $459^{\circ}$ \\
\hline Pooled SE & & 13 & 0.012 & 10 & 57 & 51 \\
\hline \multirow[t]{5}{*}{1.70} & 0.65 & $346^{c}$ & $0.321^{d}$ & $55^{d}$ & $1463^{x}$ & $2589^{a}$ \\
\hline & 1.05 & $522^{a}$ & $0.523^{\circ}$ & $108^{c}$ & $1174^{\mathrm{ab}}$ & $1788^{\circ}$ \\
\hline & 1.45 & $525^{a}$ & $0.593^{\mathrm{a}}$ & $143^{c}$ & $937^{\circ}$ & $613^{\mathrm{d}}$ \\
\hline & 1.85 & $479^{b}$ & $0.569^{\mathrm{ab}}$ & $301^{b}$ & $774^{\circ}$ & $787^{\circ}$ \\
\hline & 2.25 & $409^{e}$ & $0.556^{b}$ & $532^{\mathrm{a}}$ & $749^{b}$ & $522^{d}$ \\
\hline Pooled SE & & 16 & 0.016 & 17 & 67 & 47 \\
\hline
\end{tabular}

${ }^{a d d}$ Means within the same columns in the same dietary Lys levels with no common superscripts differ significantly $(P<0.05)$.

Means $\pm S E$ for 10 chicks with average intial body weight of $150 \pm 1 \mathrm{~g}$.

BW gain and genetic strain on the Lys requirement of broiler chickens, and concluded that males grew faster and required more Lys than females for maximum performance, which was compensated by increasing feed intake. The values expressed as $\mathrm{mg} / \mathrm{chick} /$ day obtained in this study showing females were lower than those for males, agreed with the findings of Han and Baker ${ }^{12)}$ but the values expressed as percentages of diet may be applied to males.

\section{References}

1) Austic NK, Nesheim MC. Role of kidney arginase in variations of the arginine requirement of chicks. J. Nutr., $100: 855-868.1970$.

2) Boomgaardt J, Baker DH. Effect of age on the lysine and sulfur amino acid requirement of growing chickens. Poult. Sci., 52 : 592-597. 1973.

3) Burton EM, Waldroup PW. Arginine and lysine needs of young broiler chicks. Nutr. Rep. Int., $19: 607-614.1979$.

4) Calet C. Report of committee on nutrient 
requirements for poultry. World's Poult. Sci. J., $23: 46-49.1967$.

5) Cuca GM, Jensen LS. Arginine requirement of starting broiler chicks. Poult. Sci., 69 : 13771382. 1990.

6) Dean WF, Scott HM. The development of an amino acid reference diet for the early growth of chicks. Poult. Sci., 44 : 803-808. 1965.

7) D'Mello JPFD, Lewis D. Amino acid interactions in the chick nutrition. 1 The inter relationship between lysine and arginine. $\mathrm{Br}$. Poult. Sci., $11: 299-311.1970$.

8) D'Mello JPFD, Lewis D. Amino acid interactions in the chick nutrition. 3 Interdependence in amino acid requirements. Br. Poult. Sci., 11 : 367-385. 1970.

9) Fujimura S, Yamamoto A, Kobayashi K, Ishibashi $\mathrm{T}$. Comparison of performance of amino acid analysis with high performance liquid chromatograph equipped with sodiumand lithium-type column. Bull. Fac. Agric. Nigata Univ., $46: 71-77.1994$.

10) Grau CR. Effect of protein level on the lysine requirement of chick. J. Nutr., $36: 99-108.1948$.

11) Grigor'ev NG. Opredelenie amino-kislotnoj potrebnosti brojierov. Zivotnovodstvo, $7: 55^{-}$ 60. 1967.

12) Han $Y$, Baker DH. Effects of sex, heatstress, body weight and genetic strain on the dietary lysine requirement of broiler chicks. Poult. Sci., $72: 701-708.1993$.

13) Hewitt D, Lewis D. The amino acid requirements of the growing chicks. Ö Determination of amino acid requirements. Br. Poult. Sci., $13: 449-463.1972$.

14) Hurwitz S, Sklan D, Bartov I. New formal approaches to the determination of energy and amino acid requirements of chicks. Poult. Sci., 57 : 197-205. 1978.

15) Ishibashi $T$, Kametaka M. Methionine requirements of chickens with various body weights. Agric. Biol. Chem., $49: 3493-3500.1985$.

16) Ishibashi $T$. Lysine requirement of laying hens. Jpn. J. Zootech. Sci., 56 : 827-834. 1985.

17) Jones JD, Petersburg ST, Burnett PH. The mechanism of the lysine-arginine antagonism in the chick: effect of lysine on digestion kidney arginase, and liver transaminase. $\mathrm{J}$. Nutr., 93 : 103-110. 1967.

18) Klain GJ, Scott HM, Johnson BC. The amino acid requirement of growing chick fed a crystalline amino acid diet. Poult. Sci., $39: 39-44$. 1960 .
19) Mitchell JR, Becker DE, Jensen AH, Harmon BG, Norton HW. Determination of amino acid needs of the young pig by nitrogen and plasma amino acids. J. Anim. Sci., 27 : 1327-1331. 1968.

20) Morris TR, Al-Azzawi K, Gous RM, Simpson GL. Effects of protein concentration on responses to dietary lysine by chicks. Br. Poult. Sci., 28 : 185-195. 1987.

21) Myung KH, Han IK, Park CM, Na HC. Studies on the amino acid requirements of growing broiler chicks. 1. Determination of the essential amino acid proportions. Kor. J. Anim. Sci., 27 : 288-292. 1985.

22) National Research Council. Nutrient requirements of poultry. 9th rev. ed. National Academy Press. Washington, DC. 1994.

23) Nesheim MC, Hutt FB. Genetic differences among White Leghorn chicks in requirement of arginine. Science, $137: 691-692.1962$.

24) Ohtsuka $Y$, Yoshihara M. Fitting a family of intersecting regression models with one to two intersection points. Appl. Statis., 5 : 29-39. 1976.

25) Packham RG, Payne CG. Amino acid requirements of broiler chickens. Proc. Aust. Poult. Sci. Cong., 109-113. 1972.

26) Sasse CE. Modification of the Illinois reference standard amino acid mixture. Poult. Sci., 52 : 1970-1972. 1973.

27) SAS Institute Inc. SAS User's Guide : Statistics, Version 5 ed., Cary, NC. 1985.

28) Snedecar GW, Cochran WG. Statistical methods, 7th ed., The Iowa Univ. Press. Ames, IA. 1980.

29) Stockland WL, Meade RJ, Mellie AL. Lysine requirement of growing rat:Plasma-free lysine as a response criterion. J. Nutr., $100: 925$ $-935.1970$.

30) Totsuka K, Okazaki $Y$, Yamamoto A, Koide $K$, Watanabe E, Toyomizu M. Ishibashi T. Effects of dietary crude protein and metabolizable energy on the performance of laying hens. Jpn. Poult. Sci., $30: 1-15.1993$.

31) Toyomizu M, Hayashi K. Yamashita K, Tomita $Y$. Response surface analyses of the effects of dietary protein feeding and grow th patterns in mice from weaning to maturity. J. Nutr., 118 : 86-92. 1988.

32) Ueno $K$, Koide $K$, Ishibashi T. Factors affecting arginine requirement in broilers. Anim. Sci. Technol. (Jpn.), $65:$ 9-15. 1994.

33) Yamamoto A, Ishibashi T. Usefulness of plasma lysine concentration as a parameter to estimate lysine requirement in a shorter 
period in laying hens. Anim. Sci. Technol. (Jpn.), 66: 41-48. 1995.

34) Yamamoto A, Ishibashi $T$. Lysine requirements of laying hens in a practical farm. Anim Sci. Technol. (Jpn.), 68 : 735-740. 1997.

35) Young VR, Tontisirm K, Ozalp I, Lakshmanan F, Schrimshaw NS. Plasma amino acid response curve and amino acid requirements in young men : Valine and lysine. J. Nutr., 102 : 1159-1169. 1972.

36) Zimmerman RA, Scott HM. Interrelationship of plasma amino acid levels and weight gain in the chick as infuenced by suboptimal and superoptimal dietary concentrations of single amino acids. J. Nutr., $87: 13^{-18 .} 1965$.

\title{
ブロイラーにおけるアルギニン要求量と飼料中アルギニン およびリジンの最適バランス
}

\author{
上野啓介・石橋 晃* \\ 新潟大学自然科学研究科, 新潟市 950-2102
}

報告されているプロイラーのアルギニン (Arg) 要求量は研究者により大きな差があり，これは飼料 中のリジン (Lys) 含量の影響を受けているむのと考元られる. そこで, 本試験は增体量および血墏了ミ

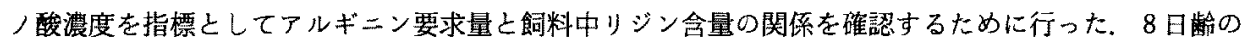
雌プロイラーを1区10羽ずつの20区にわけ，単飼し，10日間試験飼料を給与した. Arg-Lys 欠の基礎 飼料は主としてトゥモロコシ, コーングルテンミール, 大豆粕, フスマからなり, 粗タンバク質 $18.7 \%$, Arg 0.65\%，Lys 0.80\%，代謝エネルギー $3.2 \mathrm{kcal} / \mathrm{g}$ であった. Lys 4 段階, そ机ぞれ Arg 5 段階の飼料 を調製した. 各 Lys 飼料で鷄の增体量は飼料中の Arg 含量の增加にとあない増加し，之の後隇少した.

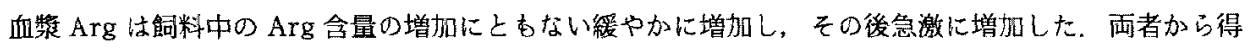
られた Arg 要求量 ( $\mathrm{Y}$, 飼料中\%) は飼料中の Lys 含量 ( $\mathrm{X}$, 飼料中\%) の関数として次式の上うに求 められた。增体量: $\mathrm{Y}=1.55 \mathrm{X}-0.21, \mathrm{r}^{2}=0.944,0.80 \leqq \mathrm{X} \leqq 1.40$, 血鼎 $\mathrm{Arg}: \mathrm{Y}=1.10 \mathrm{X}-0.26, \mathrm{r}^{2}=0.991$, $0.80 \leqq \mathrm{X} \leqq 1.70$. Lys, Arg に対する增体量の関係加ら, 最大增体量のための Lys, とArg の要求量は $1.10 \%$ と $1.36 \%$ で, $\mathrm{Arg} / \mathrm{Lys}$ 比は 1.24 であった.

日畜会報，69 (8)：760-767, 1998

現所属：日本獣医率産学部獣医畜産学部，武蔵野市 180-8502 